\title{
Potential of Rattail Fescue Powder for Weed Management
}

\author{
Madoka YAмамото and Hisashi KATO-NoGUCHI \\ Department of Applied Biological Science, Faculty of Agriculture, Kagawa University, Miki, Kagawa 761-0795, Japan
}

(Received November 13, 2014; Accepted January 9, 2015)

\begin{abstract}
Controlling weeds through allelopathy is one strategy to reduce dependency on synthetic herbicides. We investigated possible allelopathic effects of rattail fescue (Vulpia myuros (L.) C.C. Gmel.). Water extract of rattail fescue inhibited root and shoot growth of cress (Lepidium sativum L.). Powder of rattail fescue also inhibited the root and shoot growth of cress in a concentration dependent manner. The effectiveness of the water extract and powder of rattail fescue on the cress root and shoot growth was not significantly different. Allelopathic active substances may be leached from the powder into bioassay medium and those substances may inhibit the cress roots and shoots. In addition, the powder inhibited root and shoot growth of lettuce (Lactuca sativa L.), alfalfa (Medicago sativa L.), Phleum pratense L., Digitaria sanguinalis L., Lolium multiflorum Lam. Lolium rigidum Gaund., Echinochloa crus-galli (L.) Beauv. and Echinochloa colonum L. in a concentration dependent manner. Therefore, rattail fescue could be useful for a weed suppressive residue or soil additive materials in the variety of agricultural settings to reduce dependency on synthetic herbicides, which should be investigated further in the field.
\end{abstract}

Keywords : allelopathy, growth inhibitory activity, rattail fescue, weed control

\section{INTRODUCTION}

Many researches have investigated plant allelopathy for weed control purposes to develop sustainable agricultural systems (Belz, 2007; Macías et al., 2007). Plant produced variety of secondary metabolites and some of the compounds have allelopathic activity such as germination and growth inhibitory effects on other plant species (Duke et al., 2000; Macías et al., 2007). In addition, some plants show an ability to inhibit weed growth when those plants and/or residues were incorporated into the field soil as soil additives (Weston, 1996; Caamal-Maldonado et al., 2001). Therefore, allelopathy may be potentially useful for weed management options in some agriculture settings to reduce herbicide dependency.

Rattail fescue (Vulpia myuros (L.) C.C. Gmel.) belongs to the Poaceae family, is originated in the Mediterranean region, but it can now be found almost worldwide as a naturalized winter annual grass (Ball et al., 2008; Tozer et al., 2009; Tarasoff et al., 2013). Rattail fescue is used as a cover crop in some orchards because it can protect the orchards from weed invasion (Motosugi and Terashima, 2008). Rattail fescue was also reported to have an allelopathic effect (An et al., 1997; Kato-Noguchi et al., 2010). In this study, allelopathic activity of water extract and plant powder of rattail fescue was evaluated and discussed the possibility of the plant to use for the weed control purpose.

\section{MATERIALS AND METHODS}

\section{Plant material}

Rattail fescue (Vulpia myuros (L.) C.C. Gmel.) was grown on the field of Tabuse, Kumage, Yamaguchi, Japan $\left(34^{\circ} 20^{\prime} \mathrm{N}, 132^{\circ} 35^{\prime} \mathrm{E}\right)$ during November 2011-May 2012. Leaves and stems of the plants were then harvested and dried in oven for 1 week at $40^{\circ} \mathrm{C}$.

\section{Bioassay for water extracts}

Dried rattail fescue $(100 \mathrm{~g})$ was cut into small pieces and homogenized with $500 \mathrm{~mL}$ of distilled water and the homogenate was filtered with filter paper (No. 2; Toyo, Tokyo, Japan). The filtrate was then used for bioassay as a water extract.

An aliquot of the extract (final assay concentration; $0.3,1,3,10,30$ or $100 \mathrm{mg}$ of rattail fescue plant equivalent extract $\mathrm{mL}^{-1}$ ) was evaporated to dryness, dissolved in a 0.2 $\mathrm{mL}$ of methanol and added to a sheet of filter paper (No. 2) in a 3-cm Petri dish. Methanol was evaporated in a fume hood. The filter paper in the Petri dishes was moistened with $0.8 \mathrm{~mL}$ of a $0.05 \%(\mathrm{v} / \mathrm{v})$ aqueous solution of Tween 20 as described by Kato-Noguchi et al. (2013). Then, 10 seeds of cress (Lepidium sativum L.) were sown on the Petri dishes. The length of their roots and shoots was measured after $48 \mathrm{~h}$ of incubation in darkness at $25^{\circ} \mathrm{C}$. For control treatments, methanol $(0.2 \mathrm{~mL})$ was added to a sheet of filter paper in the Petri dish and evaporated as described above. Control seeds were then placed on the filter paper moistened with an aqueous solution of Tween 20. The concentrations required for $50 \%$ growth inhibition (defined as

Corresponding author: Hisashi Kato-Noguchi, fax: +81-87-891-3086, e-mail : hisashi@ag.kagawa-u.ac.jp 
$\mathrm{I}_{50}$ ) on cress roots and shoots in the assay were determined by a logistic regression analysis. The bioassay was repeated four times using a randomized design with 10 plants for each determination.

\section{Bioassay for powder}

Dried rattail fescue $(100 \mathrm{~g})$ were cut into small pieces and powdered in a mortar and pestle. An aliquot of the powder was added onto a sheet of filter paper in a 3-cm Petri dish (final assay concentration; 0.3, 1, 3, 10, 30 or 100 $\mathrm{mg}$ of rattail fescue powder $\mathrm{mL}^{-1}$ ). The filter paper in the Petri dishes was moistened with $0.8 \mathrm{~mL}$ of a $0.05 \%(\mathrm{v} / \mathrm{v})$ aqueous solution of Tween 20. Ten seeds of cress were sown on the Petri dishes and the length of their shoots and roots was determined after $48 \mathrm{~h}$ of incubation in darkness at $25^{\circ} \mathrm{C}$. For control treatments, 10 seeds were incubated in the aqueous solution of Tween 20 . The bioassay was repeated four times using a randomized design with 10 plants for each determination.

Ten seeds of lettuce (Lactuca sativa L.) and alfalfa (Medicago sativa L.) were also used as test plants and bioassay was carried out as described above. Weed species, Phleum pratense L., Digitaria sanguinalis L., Lolium multiflorum Lam. Lolium rigidum Gaund., Echinochloa crus-galli (L.) Beauv., Echinochloa colonum L. were used for bioassay. After germination in the darkness at $25^{\circ} \mathrm{C}$ for 16-120 h, 10 germinated seeds of those weeds were sown on the Petri dishes and bioassay was carried out as described above. The significant difference in the effectiveness between the water extract and powder of rattail fescue was examined by ANOVA.

\section{RESULTS AND DISCUSSION}

Allelopathic activity of water extracts of rattail fescue Allelopathic activity of water extracts of rattail fescue

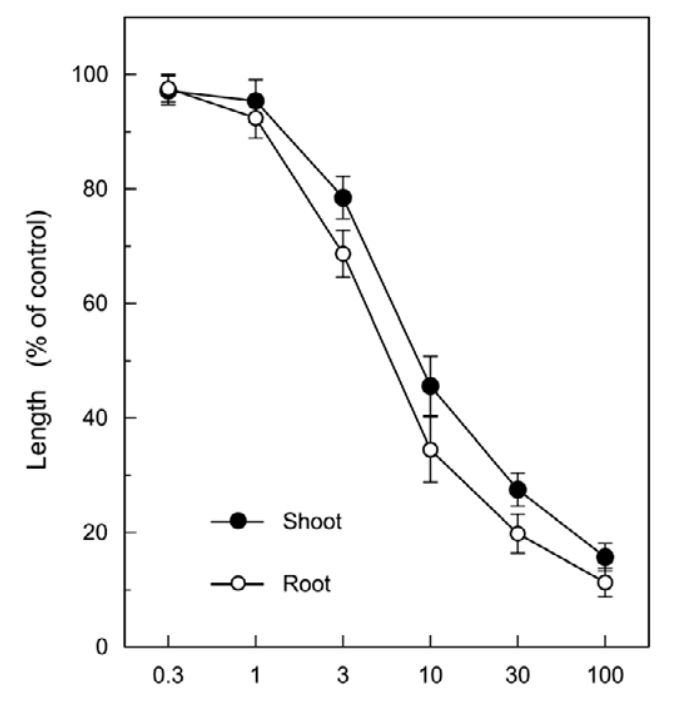

Concentration ( $\mathrm{mg}$ dry weight equivqlent extract $/ \mathrm{mL}$ )

Fig. 1 Effects of water extracts of rattail fescue on root and shoot growth of cress. Concentrations of tested samples corresponded to the extract obtained from $0.3,1,3,10$, 30 and $100 \mathrm{mg}$ dry weight of rattail fescue plants per $\mathrm{mL}$. Means $\pm \mathrm{SE}$ from four independent experiments with 10 plants for each determination are shown. was determined by using a cress bioassay due to high sensitivity of cress to phytotoxic compounds (Barnes and Putnam, 1986). Water extracts of rattail fescue inhibited root and shoot growth of cress at concentrations greater than $3 \mathrm{mg}$ equivalent extract per $\mathrm{mL}$ (Fig. 1). Increasing the extract concentration resulted in an increase in inhibition. $I_{50}$ values of the cress roots and shoots were 5.9 and $9.2 \mathrm{mg}$ equivalent extract per $\mathrm{mL}$, respectively. The present result was consistent with the result that water extracts of rattail fescue inhibited wheat germination and seedling growth (An et al., 1997).

Several phenolic acids and their related compounds were identified in water extracts of rattail fescue (An et al., 2000; 2001). Two potent growth inhibitory substances, ( - )-3-hydroxy- $\beta$-ionone and ( + )-3-oxo- $\alpha$-ionol were also isolated in an aqueous methanol extract of rattail fescue (Kato-Noguchi et al., 2010). Therefore, the water extracts may contains some of those allelopathic active substances and acts as allelopathic agents of the water extracts of rattail fescue.

Allelopathic activity of plant powder of rattail fescue

Powder of rattail fescue inhibited root and shoot growth of cress at concentrations greater than $3 \mathrm{mg}$ powder per $\mathrm{mL}$ in a concentration dependent manner (Fig. 2). $\mathrm{I}_{50}$ values of the powder on the cress roots and shoots were 5.9 and $9.2 \mathrm{mg}$ powder per $\mathrm{mL}$, respectively. The result suggests that the powder of rattail fescue also have an allelopathic effect. Allelopathic active substances may be leached from the powder into the bioassay medium and those substances may inhibit the cress root and shoot growth. Therefore, the powder may also be able to work as an allelopathic active material. In addition, the effectiveness of water extract and powder of rattail fescue on cress

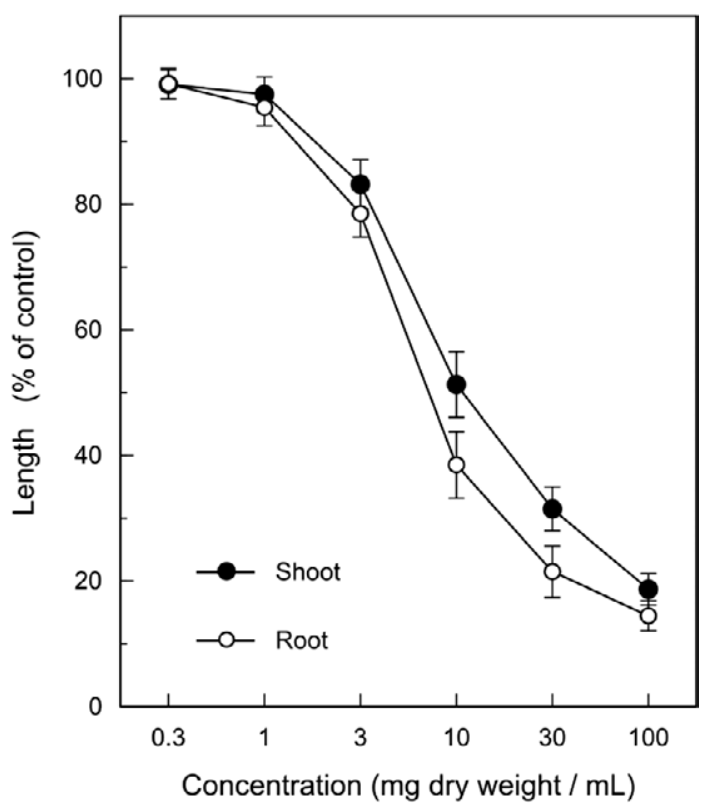

Fig. 2 Effects of plant powder of rattail fescue on root and shoot growth of cress. Concentrations of tested samples was $0.3,1,3,10,30$ and $100 \mathrm{mg}$ dry weight of rattail fescue powder per $\mathrm{mL}$. Means $\pm \mathrm{SE}$ from four independent experiments with 10 plants for each determination are shown. 

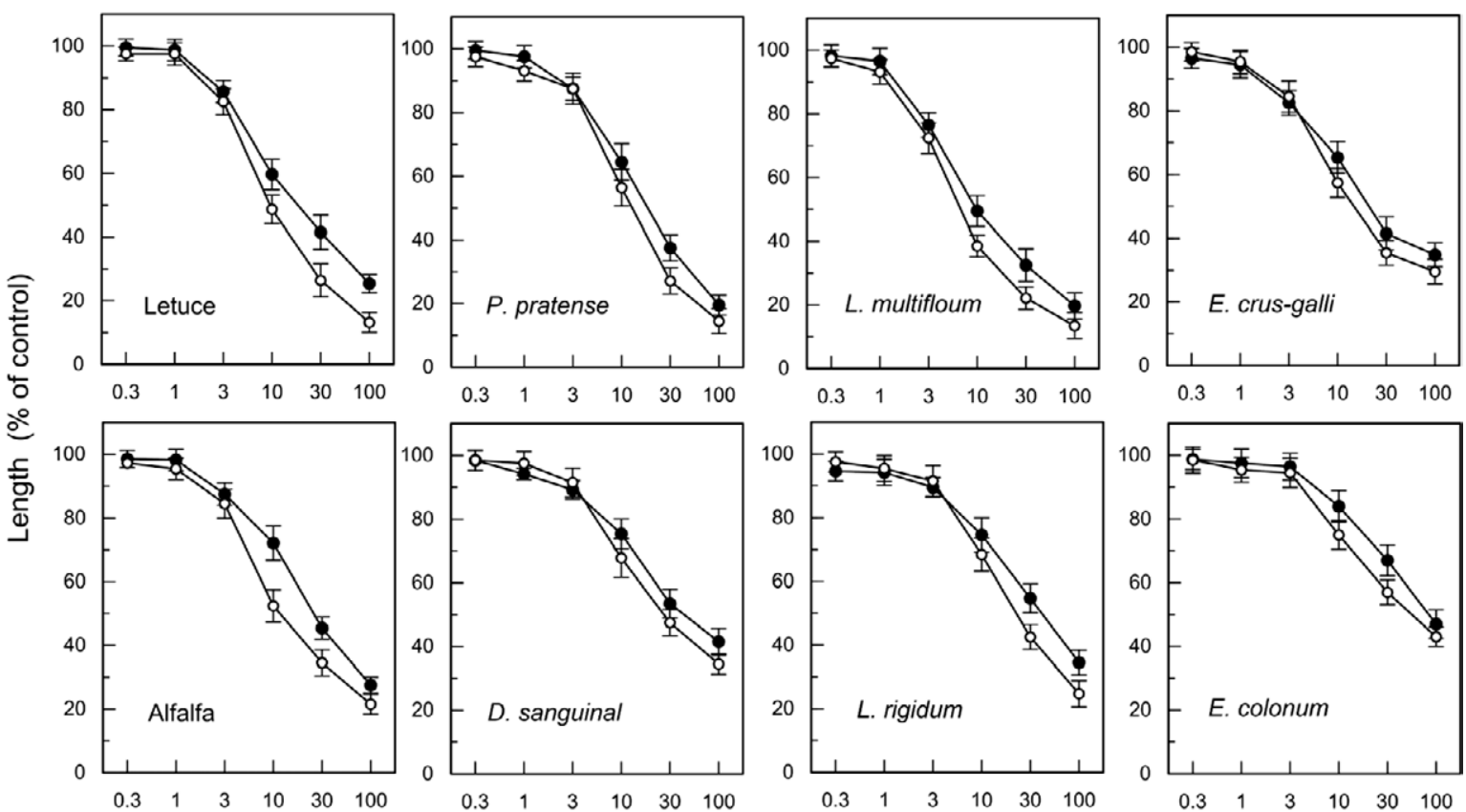

Concentration (mg dry weight $/ \mathrm{mL}$ )

Fig. 3 Effects of plant powder of rattail fescue on root $(\bigcirc)$ and shoot $(\bigcirc)$ growth of lettuce, alfalfa Phleum pratense, Digitaria sanguinalis, Lolium multiflorum, Lolium rigidum, Echinochloa crus-galli and Echinochloa colonum. Concentrations of tested samples was $0.3,1,3,10,30$ and $100 \mathrm{mg}$ dry weight of rattail fescue powder per mL. Means \pm SE from four independent experiments with 10 plants for each determination are shown.

Table $1 \mathrm{I}_{50}$ values of rattail fescue powder on root and shoot growth of test plants.

\begin{tabular}{lcc}
\hline & \multicolumn{2}{c}{$\mathrm{I}_{50}(\mathrm{mg}$ powder/mL) } \\
\hline Root & Shoot \\
\hline Lettuce & 9.8 & 19.2 \\
Alfalfa & 11.9 & 27.5 \\
P. pratense & 13.8 & 18.9 \\
D. sanguinalis & 27.5 & 44.8 \\
L. multiflorum & 6.9 & 10.2 \\
L. rigidum & 24.3 & 51.2 \\
E. crus-galli & 13.8 & 21.6 \\
E. colonum & 55.2 & 82.3 \\
\hline
\end{tabular}

The values were determined by a logistic regression analysis after bioassays.

roots and shoots was not significantly difference $(P<0.05$ level; ANOVA). Plant powder is probably more convenient to handle than water extracts for the practical use.

The allelopathic activity of the powder was evaluated with eight other test plant species. The results indicated that the powder inhibited the root and shoot growth of all test plant species including weed plants in a concentration dependent manner (Fig. 3). $I_{50}$ values of the powder on the growth of those plants were determined by a logistic regression analysis as described above (Table 1). Comparing $I_{50}$ values, the roots of $L$. multiflorum was the most sensitive to the powder and the shoots of E. colonum was the least sensitive. The dosage of $0.3,1,3,10,30$ and $100 \mathrm{mg}$ powder per 3-cm Petri dish, respectively, corresponded to approximately 4.2, 14, 42, 140, 420 and $1400 \mathrm{~kg}$ of powder per hectare. Considering the dosage and inhibitory activity of the powder, rattail fescue was relatively effective than cucumber and lemon balm (Kato-Noguchi, 2003; Thi et al.,
2008). Thus, it is possible that rattail fescue could be useful for a weed suppressive residue or soil additive material in the variety of agricultural settings to reduce dependency on synthetic herbicides. In addition, rattail fescue has been reported to have a potential to enhance crop productivity due to increase activity of ectomycorrhizal fungal (Ishii et al., 2008) and increase mineral nutrients (Motosugi and Terashima, 2008). However, it is essential to evaluate the effectiveness of the powder on weed germination and growth in the field conditions.

\section{REFERENCES}

An, M., Pratley, J. E., Haig, T., Jellett, P. 1997. Genotypic variation of plant species to the allelopathic effects of vulpia residues. Aust. J. Exp. Agric. 37: 647-660.

An, M., Haig, T., Pratley, J. E. 2000. Phytotoxicity of vulpia residues: II. Separation, identification, and quantitation of allelochemicals from Vulpia myuros. J. Chem. Ecol. 26: 1465-1476.

An, M., Pratley, J. E., Haig, T. 2001. Phytotoxicity of vulpia residues: III. Biological activity of identified allelochemicals from Vulpia myuros. J. Chem. Ecol. 27: 383-394.

Ball, D. A., Frost, S. M., Fandrich, L., Tarasoff, C., Mallory-Smith, C. 2008. Biological attributes of rattail fescue (Vulpia myuros). Weed Sci. 56: 26-31.

Barnes, J. P., Putnam, A. R. 1986. Evidence for allelopathy by residues and aqueous extracts of rye (Secale cereale). Weed Sci. 34: 384-390.

Belz, R. G. 2007. Allelopathy in crop/weed interactions - an update. Pest Manage. Sci. 63: 308-326.

Caamal-Maldonado, J. A., Jiménez-Osornio, J. J., Torres-Barragán, A., Anaya, A. L. 2001. The use of allelopathic legume cover and mulch species for weed control in cropping 


\section{YAMAMOTO AND H. KATO-NOGUCHI}

systems. Agron. J. 93: 27-36.

Duke, S. O., Dayan, F. E., Romagni, J. G., Rimando, A. M. 2000. Natural products as sources of herbicide, current status and future trends. Weed Res. 40: 99-111.

Ishii, T., Aketa, T., Motosugi, H., Cruz, A. F. 2008. Mycorrhizal development in a chestnut orchard introduced by a sod culture system with Vulpia myuros L. C. C. Gmel. Acta Hortic. 767: 429-434.

Kato-Noguchi, H. 2003. Assessment of allelopathic potential of shoot powder of lemon balm. Sci. Hortic. 97: 419-423.

Kato-Noguchi, H., Yamamoto, M., Tamura, K., Teruya, T., Suenaga, K., Fujii, Y. 2010. Isolation and identification of potent allelopathic substances in rattail fescue. Plant Grow. Regul. 60: 127-131.

Kato-Noguchi, H., Takeshita, S., Kimura, F., Ohno, O., Suenaga, K. 2013. A novel substance with allelopathic activity in Ginkgo biloba. J. Plant Physiol. 170: 1595-1599.

Macías, F. A., Molinillo, J. M. G., Varela, R. M., Galindo, J. G. G.
2007. Allelopathy — a natural alternative for weed control. Pest Manage. Sci. 63: 327-348.

Motosugi, H., Terashima, S. 2008. Nitrogen transport by hyphae of arbuscular mycorrhizal fungi between grapevine and cover crop (Vulpia myuros). Acta Hortic. 767: 361-368.

Tarasoff, C. S., Mallory-Smith, C., Ingegneri, L. 2013. Vernalization responses and subsequent fertility of two climatically distinct populations of rattail fescue (Vulpia myuros (L.) C.C. Gmel.). Weed Biol. Manage. 13: 24-30.

Thi, H. L., Lan, P. T. P., Chin, D. V., Kato-Noguchi, H. 2008. Allelopathy potential of cucumber (Cucumis Sativus) on Echinochloa crus-galli. Weed Biol. Manage. 9: 129-132.

Tozer, K. N., Chapman, D. F., Quigley, P. E., Dowling, P. M., Cousens, R. D., Kearney, G. A. 2009. Integrated management of vulpia in dryland perennial pastures of southern Australian. Crop Pasture Sci. 60: 32-42.

Weston, L. A. 1996. Utilization of allelopathy for weed management in agroecosystems. Agron. J. 88: 860-866. 